\title{
Governing online platforms: competition policy in times of platformization
}

\author{
Just, Natascha
}

\begin{abstract}
This paper argues that a paradigmatic change in competition policy is needed and empirically under way to cope with the challenges posed by economically strong online platforms and their big-data-based business models. Competition policy needs to move further away from its traditional price-oriented emphasis and increasingly focus on non-price competition, on attention markets and zero prices, and on big user data, which has become a new asset class in digital economies.
\end{abstract}

DOI: https://doi.org/10.1016/j.telpol.2018.02.006

Posted at the Zurich Open Repository and Archive, University of Zurich ZORA URL: https://doi.org/10.5167/uzh-168189

Journal Article

Accepted Version

Originally published at:

Just, Natascha (2018). Governing online platforms: competition policy in times of platformization. Telecommunications Policy, 42(5):386-394.

DOI: https://doi.org/10.1016/j.telpol.2018.02.006 


\title{
Governing online platforms: Competition policy in times of platformization
}

Accepted manuscript: Just, N. (2018). Governing online platforms: Competition policy in times of platformization. In: Telecommunications Policy, 42(5), 386-394. https://doi.org/10.1016/j.telpol.2018.02.006

\section{Highlights}

- Online platforms and their multi-sidedness have emerged as a major, controversial topic in competition policy

- Theoretical advances in industrial economics and new market conditions require a paradigmatic shift in competition policy

- This entails:

(1) a shift in attention from traditional price-oriented analyses to systematic inclusions of non-price competition factors like quality, innovation, and privacy, (2) due consideration of attention markets and the acknowledgement of markets in the absence of price, as well as

(3) alertness to the role of user data and big data in competition analyses

- Analyses of ongoing and concluded competition cases and investigations show how such a shift is being realized in practice, where uncertainties and controversies remain, and where further research is indispensable

\begin{abstract}
:
This paper argues that a paradigmatic change in competition policy is needed and empirically under way to cope with the challenges posed by economically strong online platforms and their big-data-based business models. Competition policy needs to move further away from its traditional price-oriented emphasis and increasingly focus on non-price competition, on attention markets and zero prices, and on big user data, which has become a new asset class in digital economies.
\end{abstract}

Keywords: online platforms, two-sided markets, competition policy, governance, non-price competition, attention markets, zero prices, big data 


\section{Introduction}

The governance of online platforms has become a top-priority for policy-makers, regulatory agencies, and competition authorities worldwide (e.g., European Commission, 2015, 2016a; House of Lords, 2016; OECD, 2009). Their functioning and big data-based business models have given rise to a multitude of policy questions and to much analytical uncertainty regarding the appropriate treatment of issues ranging from privacy protection to intellectual property rights. While many areas of law are affected by these developments and often simultaneously, it is competition law that has gained special prominence. This is owing, on the one hand, to the strong market positions of individual companies like Google, Facebook or Amazon (Latzer, Hollnbuchner, Just, \& Saurwein, 2016; Just \& Latzer, 2017a). In fact, the enormous global economic significance of these international players dwarfs that of any of the traditional media and communications companies. The disruptive effects of their market entry on (national) communications markets have resulted in uncertainties regarding the appropriate treatment of dominant positions in general and the presumed abuse of market power in particular. On the other hand, the economics of platform markets has contributed to the prevalence of the role of competition law and its enforcement in the debates on online platforms. This has been developed, scrutinized and formalized since the early 2000 s under the labels of two- or multi-sided markets and equivalents such as intermediation markets or platform markets (e.g., Armstrong, 2006; Caillaud \& Jullien, 2003; Evans, 2003; Rochet \& Tirole, 2003, 2006; Rysman, 2009). Altogether, online platforms and their multi-sidedness have emerged as a major, albeit controversial topic in competition policy, leading, among other things, to calls to modernize competition law (Zimmer, 2015).

This paper focuses on competition policy and challenges for the control of market dominance and anticompetitive behavior in times of platformization. Its contribution is two-fold. First, it draws from the economics of two- or multi-sided markets and argues how these theoretical insights - coupled with the rise of economically highly significant Internet companies - are forcing a paradigm change in the area of competition policy. In essence, theoretical advances and new market conditions require (1) a shift in attention from traditional price-oriented analyses to systematic inclusions of non-price competition factors like quality, innovation, and privacy, (2) due consideration of attention markets and the acknowledgement of markets in the absence of price, as well as (3) alertness to the role of user data and big data that has become a new asset class in digital economies. There is accordingly a need to expand both into new areas of inquiry (e.g., big data) and into areas that have in principle been known for a long time, yet have generally been downplayed or ignored and defined as non-competition 
goals. For example, the now prominently emphasized concepts and contentious areas like price structure and allegedly free goods, non-transaction markets (Filistrucchi, Geradin, van Damme, \& Affeldt, 2013) or attention platforms (Bundeskartellamt, 2016a) are not new to competition cases in the communications sector. They have, however, regularly been accorded a low profile or discounted outright, with the consequence that the competitive assessment and protection has often been directed only at competitors and at monetarily paying sides of the market (e.g. advertisers but not general users).

Second, the theoretical discussion is coupled with an analysis of more than 35 ongoing and concluded competition cases and investigations, which shows how - after periods of ignorance and conceptual pondering - competition authorities are now partly and hesitantly theoretically embracing such a shift in competition policy. It further shows how at the same time in practice they are struggling to reconcile all pending challenges and to take all new dimensions into consideration systematically.

The paper proceeds as follows: Section 2 briefly revisits the aspects of the economics of platform markets that indicate where increased attention from competition authorities and more research is needed. Section 3 elaborates in more detail on the focuses identified and situates these within competition investigations and policy discussions. Section 4 concludes.

\section{Multi-sided markets and where competition enforcement should focus}

Over recent decades, competition policy and its enforcement have experienced a stronger institutional linkage between economics and law (Just, 2008), aligning it, among other things, more tightly with modern industrial organization scholarship (Budzinski, 2011). In this context, the theory of two- or multi-sided markets has emerged as one of the most widely discussed topics. Hundreds of scholarly papers have been published on this issue within a short timeframe and manifold voices have been raised in favor of harnessing its theoretical suppositions, for example for competition-law enforcement in the digital economy (Auer \& Petit, 2015; Caillaud \& Jullien, 2003). The sheer magnitude of academic publications, the omnipresence of this topic in the daily news and in policy documents, as well as the ease with which this concept is generally employed, suggest a consistent corpus of assumptions and consolidated theory ready for immediate practical implementation. However, this does not stand up to closer scrutiny. There is no unified theory of two- or multi-sided markets as of yet and a great deal of divergence with regard to definitions and scope as well as inconsistencies in practical application. This should alert us to the difficulties of turning theory to policy and practice (Auer \& Petit, 2015). 
Nevertheless, the concepts on which it rests succinctly direct attention to various issues that for decades have been accorded negligible status in competition enforcement in general and in media cases in particular. This has been criticized in the past, however, with little response or impact on enforcement or policy (e.g., Just, 2000; Evans, 2011). Now that these concepts are vested and articulated in more formalized economic terms - and given the new market circumstances -they have a more decisive voice. This makes them more readily acceptable to competition authorities and courts. A fact that is also elucidated by changes to competition laws as a result of these insights, as exemplified by the 2017 revisions to the Austrian Cartel Act and the German Restraints of Competition Act (see 3.2 and 3.3).

The workings and characteristics of two- or multi-sided markets have been explained and discussed in detail elsewhere (see e.g. references above), which is why this paper pays directs attention only to those elements that require it for the subsequent analyses. These are the price structure, price allocation and zero-priced goods as well as the existence of diverse interlinked markets caused by indirect network effects between the various demand sides. These characteristics in turn direct attention to non-price competition, attention markets, and data as currency and strategic asset.

The fact that platforms coordinate the demand of at least two distinct but - due to indirect network effects - interdependent groups of customers (i.e. two interdependent demand sides) highlights the importance of the price structure, i.e. the way the total price is allocated. According to Rochet and Tirole (2006) a market is two-sided "if the platform can affect the volume of transactions by charging more to one side of the market and reducing the price paid by the other side by an equal amount; in other words, the price structure matters, and platforms must design it so as to bring both sides on board" (p. 665). The prices on each side are designed in such a way as to reflect the magnitude and direction (i.e., positive or negative) of the present indirect network effects. This may result, for example, in prices that are significantly above marginal cost on one side and significantly below such cost or even set at zero on the other side, without this being an indicator of anticompetitive behavior like predatory pricing or a sign of market power (Wright, 2004). The question of predatory pricing was recently disputed in France in a damages claim brought by Evermaps/Bottin Cartographe against Google. Evermaps contended that Google was exploiting its dominant position and engaging in predatory pricing by offering mapping products for free. While the Tribunal de Commerce de Paris granted damages to Evermaps in a first-instance decision, this was later overturned by the Paris Court of Appeal. The court acknowledged the functioning of multisided markets and argued that such pricing structures may be rational in order to attract 
customers on the other side of the market (Autorité de la concurrence, 2014; Cour d'appel de Paris, 2015).

The revenue model and thus the decision on how the price is allocated and how the product or service is sold is consequently a key component of the business model. Due to the various types of platform industries, from credit-card markets to search engines, there is also a variety of business models (Rochet \& Tirole, 2003, Latzer, Hollnbuchner, Just, \& Saurwein, 2016). Many of the new Internet companies adopt an "audience-makers” (Evans, 2003) business model, which has prevailed in traditional media markets like newspapers or television. In essence, this entails matching audiences or users to advertisers or, as it has long been described in communications research, producing users for advertisers (Smythe, 1977). This results in users paying very little or zero in monetary terms for using certain services, for example search engines or social online networks, while advertisers are charged a positive and higher price for access to them (Latzer, Hollnbuchner, Just, \& Saurwein, 2016).

Altogether, as will be explicated and scrutinized in detail in the following, it can be argued that (1) if competition on price is restricted or strategically necessitated, then companies will most likely resort to other, non-price dimensions of competition, such as quality or innovation (see 3.1). Further, even though repeatedly held otherwise in competition cases (2) markets can be constituted by free products and services and without monetary exchange (see 3.2), for example (3) by users paying with other types of currency such as attention or data, which, among other things, triggers substantial privacy concerns (see 3.3). Altogether these issues raise the questions of how to cope with these traditionally non-competition goals through competition law and what respective roles competition law and regulation should play, for example regarding privacy or data protection.

\section{New challenges for competition enforcement and research}

\subsection{Focus on non-price competition - quality, innovation, privacy}

Although price is only one dimension of competition, it has received significantly greater attention than non-price competition variables, and price theory remains central in defining competition and markets. The standard framework for delineating markets, for example, scrutinizes demand- and supply-side responses under the assumption that a hypothetical monopolist introduces a small but significant non-transitory increase in price (SSNIP), which is usually between 5 and 10 percent. However, the fact that in two- or multi-sided markets the optimal price on one side of the market may be below cost or sometimes even zero suggests that - as a strategic business decision - companies with comparable products must engage in 
non-price competition. This is what makes the acknowledgement of non-price factors and their effect on competition in future assessments so important. The fact that, in the absence of price, companies may resort to other competitive parameters may also be inferred from the recognition that price controls in various areas such as airlines or hospitals have induced nonprice competition (Hatfield, Plott \& Tanaka, 2012).

There is no conclusive definition of non-price competition and most frequently there is only an enumeration of possible variables, essentially covering an indefinite number of aspects. Generally it can be defined as any type of activity, adjustment or factor other than price that shifts the supply and demand of products and services in the market. Possible non-price variables range from advertising and other selling efforts, via changes in quality or variety, to customer service, innovation, and - lately - also privacy (see below).

The current predominance of price competition is both a legacy of the price-theory roots of industrial organization economics with its well-proven models for quantifying price and output effects (Budzinski, 2011), as well as a consequence of the challenges associated with adequately accounting for and understanding how and which non-price factors inform the demand functions of products and services (OECD, 2013). Ginsburg (1993), among others, criticized how non-price competition was only "occasionally acknowledged [...] with a nod and perhaps even a kind word about [its] social utility" to then "quickly return to the more familiar subject of price competition" (p. 83).

Until now, non-price competition has been an analytical stepchild in economics with little impact on competition enforcement, even though there is a long history of awareness and discussion about the relationship of price and non-price competition, also with regard to the media (Ray, 1951). Joseph Schumpeter (1943, here 2003), for example, raised this question 75 years ago in his description of modern capitalism and attendant processes of creative destruction. In this context he trusted that: "Economists are at long last emerging from the stage in which price competition was all they saw. As soon as quality competition [is] admitted into the sacred precincts of theory, the price variable is ousted from its dominant position" (p. 84). To date, however, nothing has dislodged price or price theory from its dominant position. This is despite advances in industrial economics that incorporate evolutionary viewpoints and question the appropriateness of static models and preoccupations with price (Audretsch, Baumol, \& Burke, 2001). Representative of many, the UK's Office of Fair Trading (2014) states that: "When evidence on price effects is available, or when theoretical models can be used to anticipate how a merger or anticompetitive practice affects 
price, competition authorities may in practice be more likely to rely on those rather than on similar analyses of quality" (p. 15).

Early and more recent efforts and proposals to additionally acknowledge non-price factors have received only scant attention. Among these are attempts at elaborating a theory of quality (Abbot, 1955), "hedonic methods" that scrutinize decreases in quality and focus on product attributes and performance competition like changes in quality, features or service (Hartman, Teece, Mitchell, \& Jorde 1993), or consumer choice approaches that aim at also reflecting consumers' non-price preferences like innovation, variety or quality (Averitt \& Lande, 2007). Additionally, there have been occasional scholarly efforts that illustrate the potential for biases in price-only merger models by showing how disregarding non-price variables in merger decisions (e.g., promotional competition), may lead to misleading estimates regarding predicted price effects (Tenn, Froeb, \& Tschantz, 2010).

Admittedly, rising awareness and recognition of non-price competition is under way, as indicated by the OECD's (2013) round table on the role and measurement of quality in competition analysis, the report of the UK's Office of Fair Trading (2014) on competing on quality, or the 2010 revisions of the horizontal merger guidelines in the USA. The latter now explicitly name non-price competition and include a section on innovation effects (US Department of Justice \& Federal Trade Commission, 2010). Similarly, innovation has started to play a role within the European merger control, alongside price and output effects (European Commission, 2016b).

This awareness and recognition is also apparent through the empirical analysis of cases. This shows that courts and enforcement agencies have generally started to acknowledge the importance of non-price variables, and companies claim it in competition cases. In their merger decisions on Microsoft/Skype (COMP/M.6281, 2011) or Microsoft/Yahoo! Search Business (COMP/M.5727, 2010) the European Commission, for example, stressed the importance of quality and innovation as significant parameters of competition, highlighting in this context, among other things, the "free" character of many services and as a consequence competition on the basis of quality (e.g., in search results). A very extensive discussion on quality competition can be found in the European Commission's merger decision on Hutchison $3 G$ UK/Telefonica Ireland (COMP/M.6992, 2014). Hutchison challenged the Commission's assessment by arguing that its quantitative analysis ignored the consequences of quality competition and how the merger would narrow the gap between competitors in terms of the quality of products and services - a stance that was subsequently repudiated by the Commission. Quality and innovation were also a subject in the merger case Hutchison $3 G$ 
UK/Telefónica UK (Case M.7612, 2016), which was blocked, among other things, because of assumed restricted ability to compete on innovation. Furthermore, in China, during the Qihoo 360/Tencent case - trying exclusionary practices and anticompetitive bundling - there was discussion of using a small but significant non-transitory decrease in quality test (SSNDQ) instead of the SSNIP test (Evans, Zhang \& Chang, 2013; Jiang, 2014; Stallibrass \& Pang, 2015). Of particular importance is also the recent acknowledgement of privacy as a possible form of non-price competition, namely in the USA in context of the Google/DoubleClick acquisition (Federal Trade Commission, 2007) or in Europe in the Microsoft/LinkedIn merger decision (Case M.8124, 2016) (see 3.3).

Despite this increased interest and the initial limited jurisprudence, not too many insights and answers on non-price competition factors have been provided thus far (Office of Fair Trading, 2014). The OECD (2013), for example, speaks of a "relative dearth of [...] practical experiences", acknowledging for example that "many authorities lack a general framework by which to assess the impact of quality as a factor within competition analysis" (p. 157). This lack results from the multidimensional and often subjective character of quality, which makes it difficult to factor quality into competition analysis or to apply single models and hypotheses to explain market interaction (Ezrachi \& Stucke, 2015; OECD, 2013; Sullivan, 1984). The question of whether this general disregard of non-price competition factors - whatever the cause - is only a teething problem, for which remedies may soon be available, is cautiously posed and assessed by Budzinski (2011) with hints at more persistent problems. Among these he highlights the non-quantifiability of many topical long-run competition dimensions such as innovation capabilities, adaptive efficiency or quality. Furthermore, due to model complexity and the intricate manageability of more complex models it appears doubtful that manageable solutions and methods will soon be available.

Altogether, as non-price issues are becoming ever more present in competition cases, these difficulties should not deter from further investigating the question of non-price competition in both theory and practice so as to guarantee a comprehensive competitive assessment.

Besides the general question of how to assess non-price competition factors and their impact, the question of how to remedy misconduct or infringements deriving from them and how to restore competition in practice is becoming increasingly relevant. Due to the dynamic nature of Internet markets many novel and unprecedented issues will arise. Remedies will therefore be as varied as the infringements, and given the general market uncertainties it is likely that competition authorities will pass responsibility onto companies, either by giving minimal guidance on the remedies to be adopted or leaving the decision completely to the company, 
though still subject to review and modification. The European Commission followed just this course in the Google search case (Case AT.39740 Google Search (Shopping)), where it only required Google to cease the infringement by arguing: "As there is more than one way [...] of bringing that infringement effectively to an end, it is for Google and Alphabet to choose between those various ways" (para. 698; see also case law cited in this). The remedy Google implemented is to auction off shopping advertising spaces to rivals, and it remains to be seen whether or not this remedy conforms to the decision. Altogether, such an approach of refraining from prescribing precise remedies is in line with the general competition law enforcement practice, which has increasingly become a matter of negotiations, commitments and consultations (e.g. Just, 2009).

\subsection{Focus on attention markets - acknowledgement of markets in the absence of price}

The preoccupation with price and price theory in competition analysis has had further consequences. It has led, for example, to the assumption that if there is no direct monetary exchange, i.e. if viewers of advertising-financed television do not pay to view or receive a program or if users do not pay to use a search service, then there is no market in an economic sense. This a priori excludes such viewer or user markets from competitive scrutiny and protection (Just, 2000). Within the recent two-sided markets literature Filistrucchi et al. (2013) refer to these kinds of media market as non-transaction markets, because of the nonobservability of direct transactions. Here - both in line with traditional communication research and with recent statements by the German Cartel Office (Bundeskartellamt, 2016a) the term attention platform or attention market is employed, because it does not a priori preclude the possibility of acknowledging markets in the absence of monetary exchange or subsequent transactions that follow upon advertising contacts for example.

The two-sided character of traditional media and the attendant pricing structure have long been acknowledged in theory and practice, even if previously in other terminology (e.g., Corden, 1952; Blair \& Romano, 1993; Evans, 2011; COMP/M.5932 News Corp/BSkyB, 2010; M.8354 Fox/Sky, 2017). Nonetheless, competition enforcement agencies and courts have usually disregarded zero-priced products and demand sides where zero prices for using a service were common. Consequently, for example, they have not assumed viewer markets in their practice either (Schmidt, 1997). Evans (2011) argues that "there is a tendency on the part of $[\ldots]$ authorities $[\ldots]$ and courts to do more hand waving than serious analysis when they encounter products and services offered for free" (p. 3). By emphasizing the increasing importance of zero-priced products in modern economies, Newman (2016) asserts that 
"antitrust institutions are, at best, only beginning to wrestle with the unique issues presented by zero-price transactions" (p. 51).

The central but contentious issue regarding whether a user market can be presumed in an economic or legal sense in cases of zero-priced services are the questions of (1) whether there is a trade relationship between the supplier of such services and the user provided that there is no monetary payment, and (2) whether user attention in terms of exposure to advertising or, as of late, data can constitute a form of payment so as to establish a trade relationship. Proponents of markets in the absence of price (Just, 2000; Höppner \& Grabenschröer, 2015; Klotz, 2016; Schmidt, 1997) argue that even though a service may be free to users their use of it is of economic value to suppliers inasmuch as they depend on users for their revenue. Furthermore, gratuity of service is generally not opposed to the concept of market, because markets can also be constituted through barter - the reciprocal service is thus attention or data. This practice especially has attracted recent attention and there are initial legislative attempts to acknowledge that payment can also take place in the form of personal or other data (see the proposed EU directive on certain aspects concerning contracts for the supply of digital content (COM(2015) 634 final). An important practical issue that accompanies this recognition is the methodological challenge of how to estimate the value of attention and data, whether it can be monetized in euro or dollar terms and whether such monetization would essentially be useful in practice. Research has started to explore the economics of personal data (Acquisti, 2010), to investigate methods for measuring the monetary value of data (e.g., OECD, 2013; Hirschprung, Toch, Bolton, \& Maimon, 2016; Malgieri \& Custers, 2017), or to address nuisance costs to advertising in multi-sided media markets (e.g., Anderson \& Jullien, 2016). The main caveats are that users generally do not value data or privacy to the same extent and advertising nuisance varies as well. Additional drawbacks, among other things, regard questions of how to account for the (welfare) effects of possible opt-outs to data collection or advertising (for the latter see Tåg, 2009), of ad-blocking possibilities (Shiller, Waldfogel, \& Ryan, 2017; Bounie, Morrisson, \& Quinn, 2017), and advertising congestion (Anderson \& Jullien, 2016). However, even if one were eventually able to scrutinize price increases in an SSNIP-like scenario, it would remain "unclear what such an increase of advertising exposure or data disclosure would mean in practical terms and how it could be measured in a meaningful way" (Haucap \& Stühmeier, 2016, p. 188). These issues are among the urgent methodological challenges that research will have to address, particularly in the light of the need to acknowledge markets in the absence of price. 
The empirical analysis regarding the acknowledgement of markets in the absence of price shows that within Europe the original neglect of the non-paying side of the market has solidified through the consistent decision-making practice of the European Commission in the context of television since the early 1990s. Pay television was identified as a separate product market from free-to-air television, with subtly changing argumentation over the years and free-to-air not being regarded as a market for competition law purposes. This distinction between the two was first argued on the grounds of its financing and specialized program mix (e.g., IV/M.110 ABC/Générale des Eaux/Canal+/W.H. Smith TV, 1991; IV/M.410 Kirch/Richemont/Telepiù, 1994; IV/M.489 Bertelsmann/News International/Vox, 1994). This was subsequently specified and upheld with the argument that there is no direct trade relationship between suppliers of free-to-air television and their viewers on the demand side as opposed to pay television, because of a lack of direct monetary exchange between them (e.g., IV/M.469 MSG Media Service, 1994; IV/M.993 Bertelsmann/Kirch/Premiere, 1998; COMP/M.1943 Telefónica/Endemol, 2000; COMP/M.4204 Cinven/UPC France, 2006; COMP/M.5121 News Corp/Premiere, 2008). Altogether, - although with evident hints of uncertainty (see below) - the Commission questioned whether free broadcasting or rather the viewer side constitutes a market in the strict economic sense, given this lack of a direct trade relationship (e.g., IV/M.553 RTL/Veronica/Endemol, 1995; IV/M.655 Canal+/UFA/MDO, 1995).

The assumption and discussion of "no market" in cases where products and services are available at zero price was subsequently initially also extended to free Internet services, for example, to online health information (IV/M.973 Bertelsmann/Burda-Hos Lifeline, 1997), search and navigation services (IV/JV.8 Deutsche

Telekom/Springer/Holtzbrink/Infoseek/Webseek, 1998), gateway services (IV/JV.1 Telia/Telenor/Schibsted, 1998), and online games (IV/JV.16 Bertelsmann/Viag/Game Channel, 1999). Such a position was also sustained in recent cases in other jurisdictions, for example in the USA in Kinderstart versus Google (KinderStart.com LLC v. Google, Inc. N.D. Cal., 2007), or in Germany in the case of the hotel-booking platform $H R S$ (Oberlandesgericht Düsseldorf, Az. VI - Kart 1/14 (V), 2015). In the former, KinderStart, a company running a directory and search engine with parenting information on young children, alleged, among other things, that Google was deflating and manipulating its PageRank; in the latter the Düsseldorf Higher Regional Court rejected an appeal by HRS against a Bundeskartellamt decision and confirmed that best-price clauses restrict competition and should be prohibited. In both cases markets for zero-priced goods were not recognized as 
markets for the purpose of competition law. In the USA the court determined that:

"KinderStart cites no authority indicating that antitrust law concerns itself with competition in the provision of free services. [...] Thus, the Search Market is not a "market" for purposes of antitrust law" (at * 5). In conformity, the German court also observed that every business activity carried out against payment is to be assigned to a market, while if there is an activity that is for payment on one side and free of charge on the other, then only the paying side is part of the market (recital 50).

While this previous decision practice appears somewhat coherent, it has been characterized by large uncertainties (also Sousa Ferro, 2014). In many instances, for example, the European Commission left the precise market definitions open, for example, regarding consumer communication apps in Microsoft/Skype (COMP/M.6281, 2011) or Microsoft/Nokia (COMP/M.7047, 2013). However, sometimes it also implicitly acknowledged the possibility of free markets, for example in the context of Internet search (COMP/M.5727 Microsoft/Yahoo! Search Business, 2010).

Most recent empirical evidence, however, shows that there has been a limited but explicit reconsideration, signifying a break with this traditional decision and policy practice. Of particular importance are the recent revisions to the German Restraints of Competition Act, which now explicitly acknowledges that nothing is opposed to the assumption that markets can be constituted by free services and products ( $\$ 18(2 \mathrm{a})$, in force since June 9,2017$)$. With this Germany has become a pioneer with regard to accepting free markets for competition law. However, it has to be mentioned that it put forward an initial proposal to recognize the viewer market as a market as early as 1999 (Wissenschaftlicher Beirat beim Bundesministerium für Wirtschaft und Technologie, 1999).

At the European level, the European Commission eventually recognized consumer communications apps for smartphones as a market in Facebook/Whatsapp (COMP/M.7217, 2014). The strongest indicator of the acknowledgement of free Internet markets as being liable to competition law, however, is the Commission's $€ 2.42$ billion fine for Google in June 2017 (Case AT.39740 Google Search (Shopping)). Google was found to be dominant in general Internet search markets and fined for having abused this market dominance by giving its own comparison shopping service an illegal advantage.

Altogether, there have been a few initial indicators of reconsideration in the light of the theoretical advances brought about by the theory of two-sided markets and the proliferation of Internet services that build on revenue models with zero prices (e.g., Barnett, 2017; Evans, 2013; Gal \& Rubinfeld, 2015; Hoofnagle \& Whittington, 2014; Newman, 2015, 2016, 2017). 
With the increase in markets where zero prices play an important role, the question of how to enforce competition law given zero-priced services needs urgent reassessment and adjustment. In this context it will be paramount to extend the appropriate protection of competition law to both competitors and users. Offering products at zero prices in multi-sided markets is not a law of nature but a profit-maximizing business strategy. Therefore there is no reason to exempt such markets from competitive scrutiny. Furthermore, it will most often not be appropriate to consider only the monetarily paying side of the market. Consequently, the non-price impact of a merger or a competitive practice on the user who receives a service for free needs to be assessed as well (e.g. decreases in quality or privacy). The recognition that the core business activity of many platforms is the selling of access to users and the producing of ever more valuable users for the purpose of monetizing their attention or data (see also 3.3) indicates that the user functions as a strategic asset, therefore also requiring the definition of such a market.

\subsection{Focus on the role of user data and big data-currency and strategic asset}

A central characteristic of Internet platforms is that they generate, collect, process and aggregate big data through sophisticated algorithmic methods in order to extract economic value from it (Latzer, Hollnbuchner, Just, \& Saurwein, 2016). This concerns both the data and contents of competitors as well as the unprecedentedly available data on individuals' personal information, behavior, communication, and transactions. The latter especially has raised a myriad of privacy questions (Büchi, Just, \& Latzer, 2017b). With personal data being a potential currency, essentially a non-monetary price paid (see 3.2), and privacy a possible non-price competitive element (see 3.1), the question regarding the relationship between regulation - in this case privacy, consumer and data protection laws - and competition law has re-emerged (e.g., European Data Protection Supervisor, 2014). In essence this is a question of whether data, consumer and privacy protection are a case for competition law or if and when they should be left to regulation. These discussions are in a sense comparable to earlier debates on such relationships, for example in the context of telecommunications liberalization or media concentration. But thus far they do not involve a comparable struggle over normative standards and value choices (Just, 2008; Just, 2009). This is also due to the fact the former were predominantly focused on abolishing sector-specific competition regulation in favor of the sole application of competition law. The discussions now center more on the efficiency and respective strength of each area of law and the allocation of competencies. The debate may become more pronounced, however, once the issue gains 
ground, but thus far there has only been limited though contested attention, for example, to the question of using competition law for privacy protection (Grunes \& Stucke, 2015; Kennedy, 2017; Ohlhausen \& Okuliar, 2015; Sokol \& Comerford, 2016).

Altogether, it is too early to predict the direction that the use of competition law for this issue will take, because there are few empirical insights from cases and policy documents.

The empirical analyses show that the European Commission has dealt with various datarelated issues in competition cases, for example in Google/DoubleClick(COMP/M.4731, 2008), Microsoft/Skype (COMP/M.6281, 2011) or Facebook/Whatsapp (COMP/M.7217, 2014), but not with privacy or privacy protection in itself as a subject of competition law. In general, the Commission has reasoned in line with a singular European Court of Justice judgment (Asnef-Equifax, Case C-238/05, 2006), which held that "any possible issues relating to the sensitivity of personal data are not, as such, a matter for competition law, they may be resolved on the basis of the relevant provisions governing data protection" (recital 63). Accordingly, in both Google/DoubleClick (COMP/M.4731, 2008) and Facebook/Whatsapp (COMP/M.7217, 2014) the Commission held similar positions. In Facebook/Whatsapp, for example, it argued that any "privacy-related concerns flowing from the increased concentration of data $[\ldots]$ do not fall within the scope of the EU competition law rules but within the scope of the EU data protection rules" (p. 29). In Microsoft/LinkedIn (M.8124, 2016) there was a hint of change in position that might open the way to a different assessment. Here the Commission acknowledged on the one hand that privacy is a non-price element and argued how foreclosure strategies by Microsoft that could result in marginalization of competitors may also restrict consumer choice in relation to privacy protection. In the attendant press release it further specified that privacy concerns "can be taken into account in the competition assessment to the extent that consumers see it as a significant factor of quality, and the merging parties compete with each other on this factor" (European Commission, 2016d). Nevertheless, apparently also cautious not to be seen as interfering with respective responsibilities, only two weeks later in Verizon/Yahoo (M.8180, 2016) it referred to the newly adopted European General Data Protection Regulation (Regulation (EU) 2016/679), which will enter into force in May 2018. In the USA, in Google/DoubleClick similar issues were raised in response to privacy advocates urging the FTC to prohibit Google's acquisition of DoubleClick on the grounds of threats to consumer privacy. On the one hand then, the FTC (2007) acknowledged having investigated adverse affects on the non-price element consumer privacy on the other hand, it also stressed that "the sole purpose of federal antitrust review of mergers and acquisitions is to identify and remedy 
transactions that harm competition" (p. 2). Altogether this discussion will not stop here, and empirical evidence suggests a likely shift from strictly separating the two to acknowledgement that there may be a case for competition law, as evidenced by investigations by national competition authorities in Germany and Italy. The German Bundeskartellamt initiated investigations against Facebook in March 2016, which are still pending and has entered into a second phase of negotiations with Facebook. This regards an alleged abuse of market power by infringing data protection rules by imposing unfair conditions of use (Bundeskartellamt, 2016b, 2017; Franck, 2016). In this context, on the question of responsibility the Bundeskartellamt (2017, p. 1-2) also reasoned that: "Where access to the personal data of users is essential for the market position of a company, the question of how that company handles the personal data of its users is no longer only relevant for data protection authorities. It becomes a relevant question for the competition authorities, too". Further, the Italian competition authority imposed a three million euro fine on Whatsapp in May 2017 on the grounds that the company "forced" its users to wholly accept the new terms and conditions, in particular regarding the sharing of their personal data with Facebook (Autorità Garante della Concorrenza e del Mercato, 2017; Zingales, 2017). Even though the Italian case was pursued under the authority's consumer-protection mandate and the Consumer Code, the definition of Whatsapp's conduct as commercial practice made it possible to combine both competition and consumer-protection considerations.

Besides possible adverse effects on users and privacy, there is a great deal of uncertainty with regard to what competitive problems may actually arise from the collection and exploitation of data. These range from entry barriers for new entrants to various types of exclusionary conducts (Autorité de la concurrence \& Bundeskartellamt, 2016). In any case, access to data has generally been identified as a possible criterion for market power $(\S 18(3 a), 4)$ in the new German Restraints of Competition Act.

Data may also become an issue with regard to mergers involving valuable data but low turnover. These mergers would thus fall outside of the turnover-based jurisdictional thresholds of EU or national merger control, thus escaping scrutiny. Through recent amendments to their competition laws, Austria and Germany have taken account of such circumstances in which the turnover is low but the value of the transaction may be substantial (e.g., §35(1a) of the German Restraints of Competition Act and §9(4) of the Austrian Cartel Act, the latter in force since November 1, 2017). Provisions with similar effect have also been in force for decades in Germany (§38) and Austria (§9) with regard to certain media mergers. 
In this case the turnover is multiplied by a certain factor so as to cover mergers that would otherwise not be scrutinized (Just \& Latzer, 2000; Just, 2015).

The impetus for the recent amendments was the Facebook/Whatsapp merger (COMP/M.7217, 2014), which did not have a European Community dimension and was only reviewed by the Commission upon referral by Facebook according to article 4(5) of the merger regulation (Council Regulation (EC) No 139/2004). Among other things, this article holds, that a merger capable of being reviewed under the national competition laws of three member states may be referred to the Commission. The question of threshold and turnover was also one of the central issues in the evaluation of and consultation on procedural and jurisdictional aspects of EU merger control (European Commission, 2016c). While the summary of the consultation, published in July 2017, reveals uncertainties as to whether reforms are necessary (European Commission, 2017), the changes in Germany and Austria may form a precedent for later changes at the European or other national levels.

\section{Conclusions}

This paper argues that a paradigmatic change in competition policy is necessary to get to grips with the challenges posed by online platforms and their big-data-based business models. Through analytical recourse to current competition cases it substantiates where and how such a shift is being realized in practice and where uncertainties and controversies remain. In order to live up to the new challenges, competition policy needs to move further away from its traditional price-oriented emphasis and increasingly focus on non-price competition such as quality, innovation or privacy. Further, there is the need for due consideration of attention markets and the acknowledgement of markets in the absence of price, and for increased attention to various types of big (user) data that have become a new asset class in digital economies.

As regards non-price factors, there is a general consensus regarding the need for the wider integration and acknowledgment of such elements. But there is still substantial uncertainty as to what factors should be taken into account and how to cope with the myriad of methodological challenges involved in extending competition analysis to factors traditionally foreign to competition enforcement.

Similarly, with regard to the acknowledgement of markets in cases of zero-pricing there is increased awareness and readiness to protect these through competition enforcement. However, it remains an open question whether this competitive protection will ultimately similarly be accorded both to users (here with a view, for example, to decreases in non-price 
elements such as quality or privacy) and competitors, or whether the latter will be given preferential treatment.

In the wake of the general acknowledgement that user data is particularly central in the business models of online platforms, the safeguarding of the user may be sought through regulation such as data, consumer and privacy protection. However, there is inchoate disagreement as to which instrument - i.e. competition law or regulation - is adequate for dealing with issues that arise in the context of increased data collection, especially regarding non-price attributes such as privacy. To the extent that non-price elements will or should be given increased attention in future mergers or cases of abuse of market power, various practices may be coverable under competition law. At the same time the discussion will increasingly revolve around the increasing entanglement of competition law with other areas of law and the relationship between competition law and regulation with respect to their appropriateness for dealing with online platform. Because there is an underlying disquiet that competition law may be weakened if broadened so as to remedy every kind of market deficit, the insights gained and arguments applied in the pending case of the Bundeskartellamt against Facebook or in other upcoming cases will be telling regarding future approaches towards online platforms at the intersection of competition law and regulation.

\section{References}

Abbott, L. (1955). Quality and Competition. New York: Columbia University Press. Acquisti, A. (2010). The Economics of Personal Data and the Economics of Privacy. Retrieved from: http://bit.ly/2EAHcAp

Anderson, S. P., \& Jullien, B. (2016). The Advertising-Financed Business Model in TwoSided Media Markets. In S. P. Anderson, S. P., D. Strömberg, \& J. Waldfogel (Eds), Handbook of Media Economics (pp. 41-90). Amsterdam: Elsevier.

Armstrong, M. (2006). Competition in two-sided markets. RAND Journal of Economics, $37(3), 668-691$.

Audretsch, D. B., Baumol , W. J., \& Burke, A. E. (2001). Competition policy in dynamic market. International Journal of Industrial Organization, 19, 613-634.

Auer, D., \& Petit, N. (2015). Two-Sided Markets and the Challenge of Turning Economic Theory into Antitrust Policy. The Antitrust Bulletin, 60(4), 426-461.

Autorità Garante della Concorrenza e del Mercato (2017). Testo Provvedimento PS10601 [Text of Provision PS10601]. Retrieved from http://bit.ly/2flccwN 
Autorité de la concurrence (2014). Avis $n^{\circ} 14-A-18$ du 16 décembre 2014 rendu à la cour d'appel de Paris concernant un litige opposant la société Bottin Cartographes SAS aux sociétés Google Inc. et Google France. [Opinion No. 14-A-18 of 16 December 2014 delivered to the Paris Court of Appeal concerning a dispute between the company Bottin Cartographes SAS and Google Inc. and Google France] Retrieved from http://bit.ly/2v8me9U

Autorité de la concurrence \& Bundeskartellamt (2016). Competition Law and Data. Retrieved from http://bit.ly/23GUVuq

Averitt, N. W., \& Lande, R. H. (2007). Using the "Consumer Choice" Approach to Antitrust Law. Antitrust Law Journal, 74(1), 175-264.

Barnett, J. M. (2017). The costs of free: commoditization, bundling and concentration. University of Southern California Legal Studies Working Paper Series. Working Paper 242. Retrieved from: http://bit.ly/2vanzLX

Blair, R.D., \& Romano, R. E. (1993). Pricing Decisions of the Newspaper Monopolist. Southern Economic Journal, 59(4), 721-732.

Bounie, D., Morrisson, V., \& Quinn, M. (2017). Do You See What I See? Ad Viewability and the Economics of Online Advertising. Retrieved from http://bit.ly/2F2MIgd

Büchi, M., Just, N., \& Latzer, M. (2017b). Caring is not enough: The importance of internet skills for online privacy protection. Information, Communication \& Society, 20(8), 1261-1278.

Budzinski, O. (2011). Modern industrial economics: Open problems and possible limits. In J. Drexl, W. Kerber, \& R. Podszun (Eds), Competition Policy and the Economic Approach (pp. 111-138). Cheltenham: Elgar.

Bundeskartellamt (2016a). Marktmacht von Plattformen und Netzwerken. [Market power of platforms and networks] Retrieved from http://bit.ly/2vtbKTk

Bundeskartellamt (2016b). Bundeskartellamt initiates proceeding against Facebook on suspicion of having abused its market power by infringing data protection rules. Retrieved from http://bit.ly/2wAP8gF

Bundeskartellamt (2017). Background information on the Facebook proceeding. Retrieved from http://bit.ly/2DxeOSq

Caillaud, B., \& Jullien, B. (2003). Chicken \& egg: Competition among intermediation service providers. RAND Journal of Economics, 34(2), 309-328.

Corden, W. (1952). The maximisation of profit by a newspaper. The Review of Economic Studies, 20(3), 181-190. 
Cour d'appel de Paris (2015). Pôle 5 - Chambre 4. Arrêt du 25 novembre 2015, No. 12/02931. [Pole 5 - Chamber 4. Decision of 25 November 2015, No. 12/02931] Retrieved from http://bit.ly/1IeFuoo

European Commission (2015). Communication from the Commission to the European Parliament, the Council, the European Economic and Social Committee and the Committee of the Regions. A Digital Single Market Strategy for Europe. COM(2015) 192 final.

European Commission (2016a). Communication from the Commission to the European Parliament, the Council, the European Economic And Social Committee and the Committee Of The Regions. Online Platforms and the Digital Single Market. Opportunities and Challenges for Europe. SWD(2016) 172 final.

European Commission (2016b). EU merger control and innovation. Retrieved from http://bit.ly/2FE3jWX

European Commission (2016c). Evaluation of procedural and jurisdictional aspects of EU Merger Control. Retrieved from http://bit.ly/2vBkUwV

European Commission (2016d). Mergers: Commission approves acquisition of LinkedIn by Microsoft, subject to conditions. Retrieved from http://bit.ly/2he9Pva

European Commission (2017). Summary of replies to the Public Consultation on Evaluation of procedural and jurisdictional aspects of EU merger control. Retrieved from http://bit.ly/2vDhQkO

European Data Protection Supervisor (2014). Privacy and competitiveness in the age of big data: The interplay between data protection, competition law and consumer protection in the Digital Economy. Retrieved from http://bit.ly/2u1mYvl

Evans, D. S. (2003). Some Empirical Aspects of Multi-sided Platform Industries. Review of Network Economics, 2(3),191-209.

Evans, D. S. (2011). The Antitrust Economics of Free. Retrieved from http://bit.ly/2va20L9

Evans, D. S. (2013). Attention to Rivalry among Online Platforms and Its Implications for Antitrust Analysis. Coase-Sandor Institute for Law \& Economics Working Paper No. 627. Retrieved from http://bit.ly/2wiD6ZY

Evans, D. S., Zhang, V. Y., \& Chang, H. H. (2013). Analyzing Competition Among Internet Players: Qihoo 360 v. Tencent. CPI Antitrust Chronicle, 1, 1-25.

Ezrachi, A., \& Stucke, M. E. (2015). The Curious Case of Competition and Quality. Journal of Antitrust Enforcement, 3(2), 227-257. 
Federal Trade Commission (2007). Statement of Federal Trade Commission Concerning Google/DoubleClick FTC File No. 071-0170. Retrieved from http://bit.ly/2wimrWJ

Filistrucchi, L., Geradin, D., van Damme, E., \& Affeldt, P. (2013). Market Definition in Two-

Sided Markets: Theory and Practice. TILEC Discussion Paper No. 2013-009.

Retrieved from http://bit.ly/2vtv0Ap

Franck, J.-U. (2016). Eine Frage des Zusammenhangs: Marktbeherrschungsmissbrauch durch rechtswidrige Konditionen [A Question of Nexus: Abuse of Market Dominance through Unlawful Trading Conditions]. Zeitschrift für Wettbewerbsrecht, 2, 137-164.

Gal, M. S., \& Rubinfeld, D. L. (2015). The Hidden Costs of Free Goods: Implications for Antitrust Enforcement. New York University Law and Economics Working Papers. Paper 403. Retrieved from http://bit.ly/2vBtjR1

Ginsburg, D. H. (1993). Nonprice competition. Antitrust Bulletin, 38(1), 83-111.

Grunes, A. P., \& Stucke, M. E. (2015). No Mistake About It: The Important Role of Antitrust in the Era of Big Data. Retrieved from http://bit.ly/2fiEisv

Hartman, R., Teece, D., Mitchell, W., \& Jorde, T. (1993). Assessing Market Power in Regimes of Rapid Technological Change. Industrial and Corporate Change, 2(3), $317-350$.

Hatfield, J. W., Plott, C. R., \& Tanaka, T. (2012). Understanding Price Controls and Nonprice Competition with Matching Theory. American Economic Review, 102(3): 371-375.

Haucap, J., \& Stühmeier, T. (2016). Competition and antitrust in Internet markets. In J. M. Bauer, \& M. Latzer (Eds), Handbook on the Economics of the Internet (pp. 183-210). Cheltenham: Elgar.

Hirschprung, R., Toch, E., Bolton, F., \& Maimon, O. (2016). A methodology for estimating the value of privacy in information disclosure systems. Computers in Human Behavior, 61, 443-453

Hoofnagle, C. J., \& Whittington, J. (2014). Free: Accounting for the Costs of the Internet's Most Popular Price. UCLA Law Review, 61, 606-670.

Höppner, T., \& Grabenschröer, J. F. (2015). Marktabgrenzung bei mehrseitigen Märkten am Beispiel der Internetsuche [Market definition in case of multisided markets using the example of Internet search]. Neue Zeitschrift für Kartellrecht, 3(4), 162-168.

House of Lords (2016). Online Platforms and the Digital Single Market. Retrieved from http://bit.ly/2ucrIxp 
Jiang,T. (2014). The Qihoo/Tencent Dispute in the Instant Messaging Market: The First Milestone in the Chinese Competition Law Enforcement? World Competition, 37(3), 369-390.

Just, N. (2000). Die Kontrolle der Marktmacht in der Mediamatik [The control of market power in mediamatics]. In M. Latzer (Ed.). Mediamatikpolitik für die Digitale Ökonomie. eCommerce, Qualifikation und Marktmacht in der Informationsgesellschaft (pp. 247-285). Innsbruck-Wien: Studienverlag.

Just, N. (2008). Electronic Communications Between Regulation and Competition Law. IPMZ-Mediachange Workingpaper. Retrieved from http://bit.ly/2vaj0B1.

Just, N. (2009). Measuring media concentration and diversity: New approaches and instruments in Europe and the US. Media, Culture \& Society, 31(1), 97-117.

Just, N. (2015). Competition/Antitrust/Antimonopoly Law. In R. Mansell, \& P. H. Ang (Eds.). The International Encyclopedia of Digital Communication and Society (pp. 114). Hoboken: John Wiley \& Sons.

Just, N., \& Latzer, M. (2000). EU competition policy and market power control in the mediamatics era. Telecommunications Policy, 24(5), 395-411.

Just, N., \& Latzer, M. (2017a). Governance by algorithms: Reality construction by algorithmic selection on the internet. Media, Culture \& Society, 39(2), 238-258.

Kennedy, J. (2017). The Myth of Data Monopoly: Why Antitrust Concerns About Data Are Overblown. Retrieved from http://bit.ly/2ucD98c

Klotz, M. (2016). Google und Facebook im Kontext von Art. 102 AEUV [Google and Facebook in the context of Article 102 TFEU]. Wirtschaft und Wettbewerb, 2, 58-65

Latzer, M., Hollnbuchner, K., Just, N., \& Saurwein, F. (2016). The economics of algorithmic selection on the Internet. In J. M. Bauer, \& M. Latzer (Eds.). Handbook on the Economics of the Internet (pp. 395-425). Cheltenham: Elgar.

Malgieri, G., \& Custers, B. (2017). Pricing privacy - the right to know the value of your personal data. Computer Law and Security Review, available online 21 September 2017. Retrieved from http://bit.ly/2ELzJlx

Newman, J. M. (2015). Antitrust in Zero-Price Markets: Foundations. University of Pennsylvania Law Review, 164, 149-206.

Newman, J. M. (2016). Antitrust in Zero-Price Markets: Applications. Washington University Law Review, 94(1), 49-111.

Newman, J. M. (2017). The Myth of Free. Retrieved from http://bit.ly/2ueX4Ya

OECD (2009). Two-sided Markets. DAF/COMP(2009)20. 
OECD (2013). Exploring the Economics of Personal Data: A Survey of Methodologies for Measuring Monetary Value. OECD Digital Economy Papers, No. 220, OECD

Publishing, Paris. Retrieved from: http://bit.ly/2o5kUkb

OECD (2013). The Role and Measurement of Quality in Competition Analysis. Retrieved from http://bit.ly/2uXZsll

Office of Fair Trading (2014). Competing on Quality - Literature Review. Retrieved from http://bit.ly/2uvkFz5

Ohlhausen, M. K., \& Okuliar, A. P. (2015). Competition, Consumer Protection, and the Right [Approach] to Privacy. Antitrust Law Journal, 80(1), 121-156.

Ray, R. H. (1951). Competition in the Newspaper Industry. Journal of Marketing, 15(4), 444456.

Rochet, J.-C., \& Tirole, J. (2003). Platform Competition in Two-Sided Markets. Journal of the European Economic Association, 1(4), 990-1029.

Rochet, J.-C., \& Tirole, J. (2006). Two-sided markets: a progress report. RAND Journal of Economics, 37(3), 645-667.

Rysman, M. (2009). The Economics of Two-Sided Markets. The Journal of Economic Perspectives, 23(3), 125-143.

Schmidt, K.-E. (1997). Gibt es einen Fernsehzuschauermarkt im Sinne des Gesetzes gegen Wettbewerbsbeschränkungen? [Is there a television viewer market within the meaning of the Act against Restraints of Competition?] ZUM - Zeitschrift für Urheber- und Medienrecht, 41(6), 472-478.

Schumpeter, J. A. (2003). Capitalism, Socialism and Democracy. London: Routledge.

Shiller, B., Waldfogel, J., \& Ryan, J. (2017). Will Ad Blocking Break the Internet? NBER Working Paper 23058. Retrieved from http://bit.ly/2o2r0Sd

Smythe, D. (1977). Communications: Blindspot of Western Marxism. Canadian Journal of Political and Social Theory, 1(3), 1-27.

Sokol, D. D., \& Comerford, R. E. (2016). Does Antitrust Have a Role to Play in Regulating Big Data? Retrieved from http://bit.ly/2ugFh2N

Sousa Ferro, M. (2014). "Ceci n'est pas un marché”: gratuity and competition law. Retrieved from http://bit.ly/2v7FZyk

Stallibrass, D., \& Pang, S. (2015). Clash of Titans: How China Disciplines Internet Markets. Journal of European Competition Law \& Practice, 6(6), 418-423.

Sullivan, E. T. (1984). On Nonprice Competition: An Economic and Marketing Analysis. University of Pittsburgh Law Review, 45, 771-802. 
Tåg, J. (2009). Paying to remove advertisements. Information Economics and Policy, 21, $245-252$

Tenn, S., Froeb, L., \& Tschantz, S. (2010). Mergers when firms compete by choosing both price and promotion. International Journal of Industrial Organization, 28, 695-707.

US Department of Justice, \& Federal Trade Commission (2010). Horizontal Merger Guidelines. Retrieved from http://bit.ly/21jA9Tt

Wissenschaftlicher Beirat beim Bundesministerium für Wirtschaft und Technologie (1999). Offene Medienordnung. Retrieved from http://bit.ly/2rqBpva

Wright, J. (2004). One-sided Logic in Two-sided Markets. Review of Network Economics, 3(1), 44-46.

Zimmer, D. (2015). Digital Markets: New Rules for Competition Law. Journal of European Competition Law \& Practice, 6(9), 627-628.

Zingales, N. (2017). Between a rock and two hard places: WhatsApp at the crossroad of competition, data protection and consumer law. Computer Law \& Security Review, $33(4), 553-558$. 